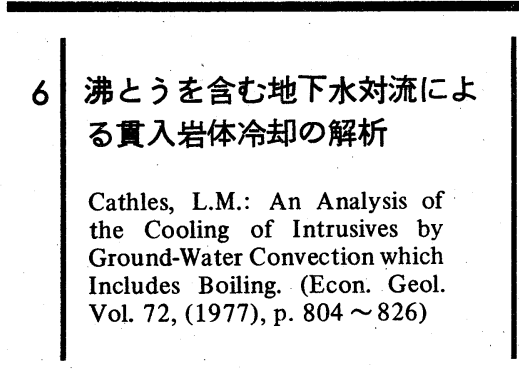

火成岩の貫入による地殼中の温度の空間 的・時間的变化は, 熱伝導による冷却過程 については従来から研究されているが, 流 体の対流による冷却については十分に解明 されていない。熱水成鉱床, 特に斑岩銅鉱 床の生成と貫入岩との関係や, 貫入岩周辺 の変質における循環地下水の役割, あるい は地熱系の生成の考察に際しては, 地下水 の対流による冷却過程の研究が重要である。 本論文では, 水の性質を考慮して地下水に よる深成岩の対流冷却を, モデル設定条件 を変えて検討している。また, 流体の沸と う, 凝縮の熱水生成に与える熱的影響につ いても検討を加えており, 地熱探査や斑岩 銅鉱床の成因的研究に関する重要な基礎的 資料を提供している。

基本的特徴を明らかにするためにモデル 化を極力簡単にしている。複雑な条件は基 本的特徴の考察の際に加えられている。マ グマは 700 Cで突然に水に飽和し, 通常の 地温勾配, 均質な透水性の破砕された地層 に貫入するものと考える。火成岩の透水性 は初期から被貫入地層と同一と仅定する。 検討の焦点は専ら火成岩貫入後の流体の対 流による冷却過程にあてられている。本モ デルの最大の久点は熱水の塩濃度を一定と する仮定である。地熱, 鉱物沈殿などの現 象を説明するには塩濃度の变化による影響 も考慮しなければならないが, 複雑になる ので本文では直接には扱わない。計算に際 して, 熱水の粘性, 密度, エンタルピーに ついては温度, 圧力の影響を考慮している が,これにより水の沸とう, 凝縮による影 響を説明することができる。

モデルの計算には半径 $0.75 \mathrm{~km}$, 高さ $2.25 \mathrm{~km}$, 頂部の深さ $2.75 \mathrm{~km}$ の深成岩体 を想定し, 周辺の岩石の透水係数を 0 , $0.05,0.25$ ミリ・ダルシー $(\mathrm{md})$ として行 なわれた。岩体冷却中におきる化学反応に よる発熱は $36 \mathrm{Cal} / \mathrm{g}$ (深成岩)であり, 冷却 による放熱は $324 \mathrm{Cal} / \mathrm{g}$ (深成岩) と仮定し た。透水係数 $0.05 \sim 0.5$ は破砕した火成岩 ではむしろ低い值である。罒には透水係数 を変えた場合の結果が示してある。透水係 数 0 , つまり伝導のみによつて冷却する場

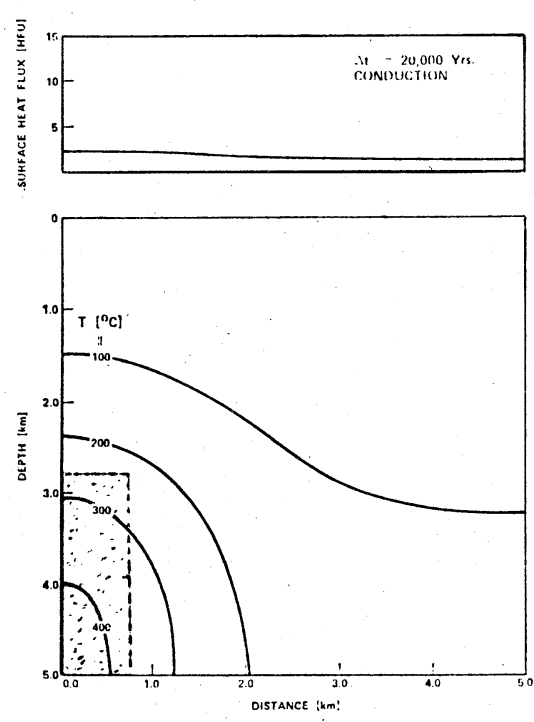

第 $6 \cdot 1$ 図 火成岩貫入後 20,000 年目 における熱伝導のみによ る冷却の状況

（上図は地表における熱流量 HFU， 下図の実線は地殼中の等温線 )

合には，地表における最大熱流量は，火成 岩貫入後 65,000 年経過して生じ, その值は $3.4 \mathrm{HFU}$ あ゙あ。透水係数が $0.05 \mathrm{md}$ の場 合には, 冷却は早められ, 地表における最 大熱流量は火成岩貫入後 35,000 年に 4.9 HFU となる。透水係数が $0.25 \mathrm{md}$ の場合は, 火成岩貫入の 10,000 年後に最大熱流量 47 HFUに達し, 透水係数が $0.5 \mathrm{md}$ であれば 6,500 年後に最大值 $69 \mathrm{HFU}$ となる。透水係 数 $0.25 \mathrm{md}$ 以上の場合には火成岩体の上で は $500{ }^{\circ} \mathrm{C}$ に達し, ここに蒸気相が生成し, 地熱資源となり得る。

透水係数が $0.25 \mathrm{md}$ の場合, 温泉活動のよ うに地表に流体の流出があると, 貫入の 7,750 年後に熱流量は最大値 $170 \mathrm{HFUに}$ 達 する。貫入が浅い所まで達すると, 蒸気相 の発生範囲が広くなり, 地表への影響も早 く表われるが, 蒸気の粘性は液相よりも大 きいので流体量はむしろ少なくなる。貫入 岩体の径が大きくなると, 蒸気発生域は広 くなり, 対流は岩体の端に集中し，そこに 第二の対流域ができる。地表の最大熱流量 の位置は岩体の端の上に表われる。

対流の量は流線束から計算されるが, 透 水係数が $0.05 \mathrm{md}$ の場合, 100,000 年間に 1 $\mathrm{cm}^{2}$ 当り $90 \mathrm{~kg}$ の水が流れることが計算で 求められた。 $0.25 \mathrm{md}$ の場合は $250 \mathrm{~kg}, 0.5$ $\mathrm{md}$ の場合は $300 \mathrm{~kg}$ と求められた。初期熱 異常の熱量が限られているので, 対流量は 透水係数と直線関係にはない。

透水係数を $0.25 \mathrm{md}$ とした場合の 火成岩 貫入後 4,800 5,000 年間の対流している流

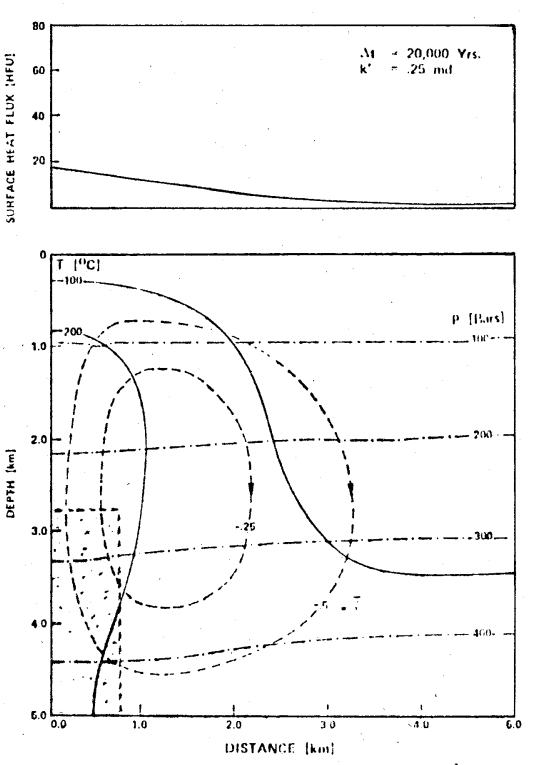

第 6.2図火成岩貫入後 20,000 年目, 地層の透水係数が $0.25 ミ$ リダルシーの場合の冷却 の状況

（下図の破線は流体の対流を，一 点破線は等圧線を示す）

体の比容積, 見掛熱容量, 粘性も求められ ている。岩体直上の高比容積域は流体の対 流の駆動力となつているが, 最大値は 400 ○における $1.67 \mathrm{~cm}^{2} / \mathrm{g}$ である。粘性は地表 の $1 / 5$ の範囲が大きく, 対流が容易におき ることを示している。また， 5,000 年後の 最大流量は $15 \mathrm{~g} / \mathrm{cm}^{2}$ ・年と求められた。

以上の結果を地熱地帯の現象と比較検討 している。ニュージーランドのワイラケイ では平均熱流量は $50 \mathrm{HFU}(50 \times 50 \mathrm{~km})$ で 現モデルとよく似ている。現モデルからは 地表の高い熱流量が持続する時間は短かく, 火成岩貫入後 20,000 年以内であり, 蒸気 卓越域の存在は $5,000 \sim 10,000$ 年とさらに 短いと結論されている。透水係数 $0.25 \mathrm{md}$ は地熱生産井の経済的維持には必要最低值 である。また, 単独岩体の場合には, 大き な地熱系は地表に未だ高熱流量の徵候の表 われていない地域の地表下にあるはずで, 最大熱流量が地表に表われる頃には地下の 蒸気卓越域は収縮していることになる。

現モデルは斑岩銅鉱床の成因的考察にも 資料を提供している。現モデルの大きさの 岩体中に $0.05 \mathrm{wt} \%$ の $\mathrm{u}$ が含まれ, これが 熱水によつて運搬され $1 \mathrm{~g} / \mathrm{kg}$ (熱水) の濃 度低下を伴う沈殿によつて $0.43 \%$ の $200 \times$ $1,000 \mathrm{~m}$ の大きさの斑岩銅鉱体を形成する と仮定すると, 必要な熱水は $216 \mathrm{~kg} / \mathrm{cm}^{2}$ となり,そのためには透水係数は $0.25 \mathrm{md}$ 以上でなければならない。火成岩貫入の 
2,000 年後ならば $350^{\circ} \sim 250^{\circ} \mathrm{C}$ の温度域は 鉱体の位置とよく一致するが， 2,000 年以 上経過すると等温線間隔が広くなり鉱体と あわない。また， 2,000 年間の流量は 0.25 $\mathrm{md}$ の場合 $15 \mathrm{~kg} / \mathrm{cm}^{2}$ で極めて少ない。 $216 \mathrm{~kg} / \mathrm{cm}^{2}$ の流量を得るためには $3.5 \mathrm{md}$ の透水係数が必要である。透水係数が 0.25 $\mathrm{md}$ の場合, 火成岩貫入後 100,000 年には熱 異常はほとんど認められないが，それまで に流れる流量は $250 \mathrm{~kg} / \mathrm{cm}^{2} に$ 過ぎない。し たがつて，一時に多量の流体が対流するこ とは著しく温度勾配を乱すことになり，鉱 林の生成をうまく説明できない。沸とうや 塩濃度の変化を考慮に入れて説明せざるを 得ない。

冷却中に貫入岩体上に生ずる等塩濃度線 の上向きの盛り上りは，等温線の盛り上り の移動よりも早い。これは貫入岩体の上で は温度が上昇する前に地層中の水の塩濃度 が上昇することを示している。このことか ら，鉱化作用は火成岩貫入に引続いて，ま だ比較的温度が高いうちに行なわれるもの と推定される。また, 塩類は水の蒸気圧曲 線を高温・高圧側に延長するので，深部に おいても沸とうが生ずることを示している。

（東大 武内寿久䭱）

\section{$7 \boldsymbol{K}$ 值測定に基づくガス突出危 険の早期検知 \\ H. Janas und K. Winter: Früher- kennung der Gasausbruchsgefahr auf der Grundlage der K-Wert- Bestimmung. (Glückauf-Forsch- ungshefte 38 (1977) H.4 S.131 $\sim 138$ )}

Bochum にあるウェストファリア州鉱山

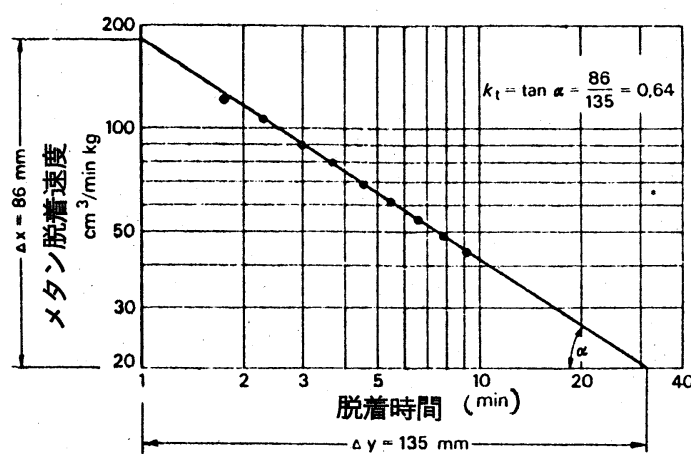

$\leftarrow$

第 $7 \cdot 1$ 図

石炭のメタン

脱着速度 $K_{t}$ 值 の測定

第 7.3 図 54 番層,南向 1 番坑道のカ ス突出範囲の $K_{t}$ 値と $V_{1}$ 值

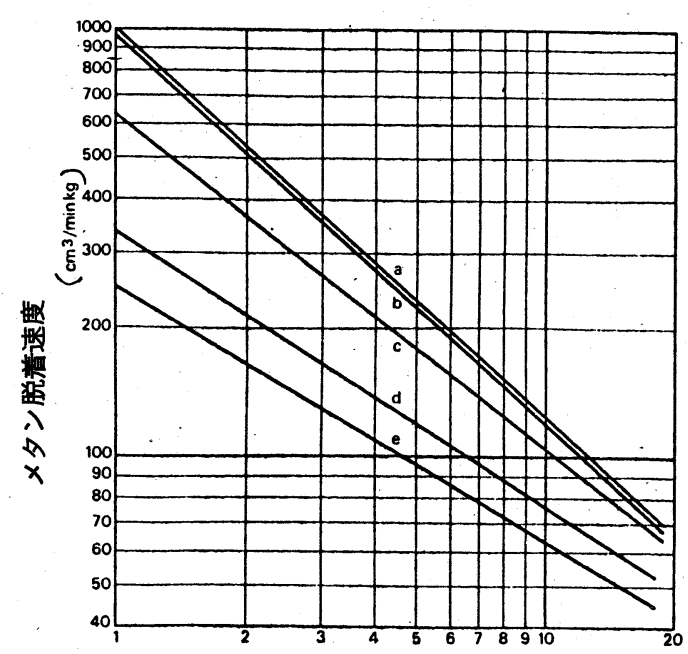

脱盖時間 $t$

第 $7 \cdot 2$ 図 各種 $K_{t}$ 値の場合のメタン脱着速度

値を示す突出した地点から 8〜 $17 \mathrm{~m}$ 離れた 地点で, 低い $K_{t}$ 値と $\dot{V}_{1}$ 值が得られている。 従来の経験から, ガス突出の危険性の評 価は次のような規準で行なつている。すな わち, $K_{t}$ 值が $0.61 \sim 0.68$ までの試料の全 体に占める割合が $70 \%$ 以上でかつ 0.75 以 上のものがない場合は危険性なし。 $K_{t} 0.61$ 〜 0.68 の割合が $70 \%$ よりさい場合では, 0.75 以上の割合が $5 \%$ よりさければガス 突出の可能性あり, 逆に 0.75 以上の割合が $5 \%$ よ大きければガス突出の危険ありと している。

$\Delta P_{0-60}$ 值のガス突出性評価の限界は 15

(Torr) であるが, これと $K_{t}=0.75$ との
財団の通気試験所において開 からの脱着特性によるガス突

従来の $V_{1}$ 法 (石炭試料 $10 \mathrm{~g}$ が 35 秒から 70 秒間の脱着メ タンガス量による突出危険度 9判定）や $\Delta P_{0}-60$ 法（封圧 に脱着するメタンガスによる ガス・石炭突出は, 地質的擾乱のあると ころで最も多く生じるが，第 $7 \cdot 3$ 図は Ibbenbüren 炭鉱の 54 番層南向坑道上で, Theodor断層の西側で起きた突出例の両指
○東側炭壁 ○西側炭壁 ○両炭壁で一致
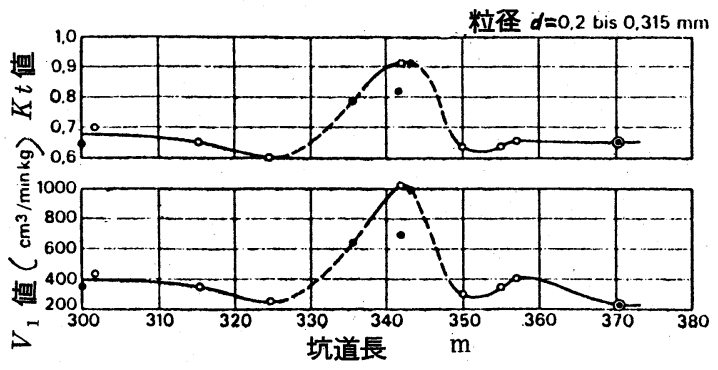
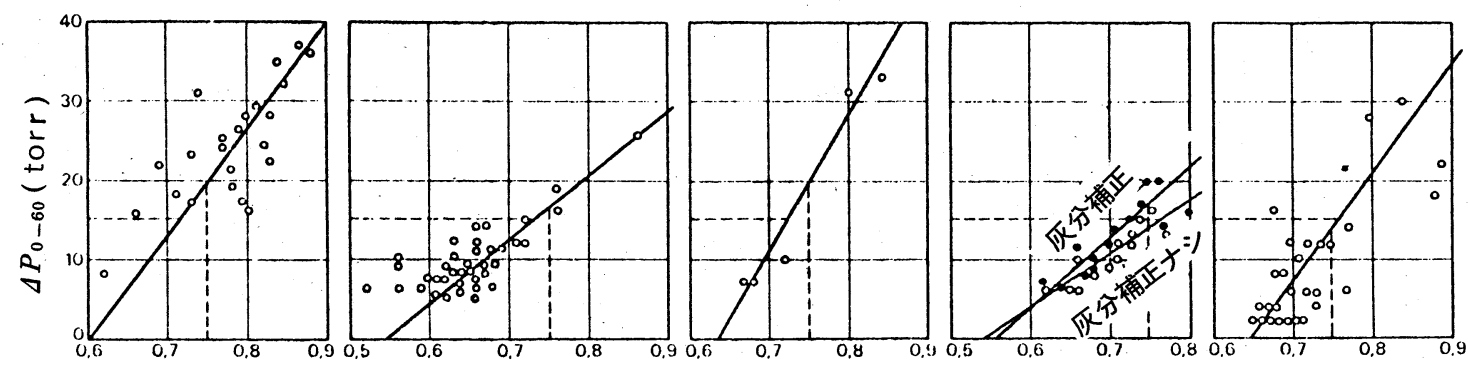

第 $7 \cdot 4$ 図 5 炭鉱の石炭 試料について の $\Delta P_{0-60}$ と $K_{t}$ との関係

$116<48>$ 
関係をいくつかの炭鉱のガス突出性の強い 石炭試料についてみたのが，第 7.4 図であ る。ここでは, 両者は大体良い一致を示し ているが，常にそうとはいえない。

結論として， $\dot{V}_{1}$ 值が石炭試料のガス包蔵 量, 粒径, 灰分, 重量, 炭化度などの影響 を受けるのに対して, $K_{t}$ 值はこれらと無関 係である。探查ボーリングの石炭試料の $K_{t}$ 値を測定して, 局部的な擾乱地帯の突出 ゾーンや鉱巣的突出ゾーンの早期検知が可 能である。この場合, $K_{t}$ 值が大きくばらつ くときが, 突出ゾーンへの接近の疑いがあ り， $\dot{V}_{1}$ 值を用いた推定メタン脱着量が $9 \mathrm{~m}^{3}$ $/ \mathrm{t}$ より多く，Kt $K_{t}$ 值が 0.75 より大きい試料 の割合が $5 \%$ より多い場合は, ガス突出の 䂆方対策を早急にとるべきである。予防対 策の効果の程度は, 現場での $\dot{V}_{1}$ 值測定によ つて評価できる。なお当試験所では, これ らの現場での測定用に電気的な自動脱着測 定器を開発した。（九大 後藤 研）

$$
8 \mid \begin{aligned}
& \text { ケーシングの破壊強度におよ } \\
& \text { ぼすケーシングの摩耗の影響 } \\
& \text { (第 } 1 \text { 報 継手部の漏れ ) } \\
& \text { W.B. Bradly: The Effect of Cas- } \\
& \text { ing Wear on the Burst Strength } \\
& \text { of Casing. (Trans. ASME, Series } \\
& \text { B, Vol. 98, No. 2, May (1976), } \\
& \text { p. 681 685) }
\end{aligned}
$$

本報はケーシングの摩耗が内圧と外圧の 作用下におかれたケーシング継手部の流体 の漏れ圧力におよぼす影響について論じ， さらに, ねじ山の飛び越しによるケーシン グの破壊について論じている。

\section{（1）ケーシング継手部の漏れ}

ヶーシングが内圧と外圧を同時に受ける 場合の継手部の漏れ圧力は次式で表わされ る。

1. 内圧が外圧より大きい場合 $\left(P_{i}>P_{o}\right)$ $P_{\text {leak internal }}=\frac{U_{D} E\left(W^{2}-d_{1}^{2}\right)}{2 d_{1} W^{2}}+P_{o}$

2. 外圧が内压より大きい場合 $\left(P_{o}>P_{i}\right)$

$P_{\text {leak external }}=\frac{U_{D} E\left(d_{2}^{2}-D_{i}^{2}\right)}{2 d_{i} D_{i}^{2}}+P_{i}$ …....... (2)

両式で， $P_{i}, P_{o}$ はそれぞれヶーシングに 負荷する内压および外圧で, $P$ leak internal,

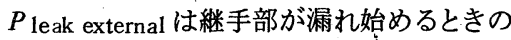
内圧および外压， $U_{D}$ は締めしろ直径， $E$ は 縱弹性係数, $W$ はカップリングの外径, $d_{1}$ は締りばめしたときのバイプ先端 (ピンの 先端) でのカップリングネジ部の谷径, $d_{2}$ は締りばめしたときのカップリング端部に おけるパイプネジ部の谷径で $D_{i}$ は継手部 のピンの内径である。

(1)式と(2)式より，継手部で内圧が支配的 なときは内側のケーシングネジ部の先端で 流体が密封され, 外圧が支配的なときは外 側のカップリングネジ部の端部で密封され ることが知れる。第 $8 \cdot 1$ 図は，10 $\frac{3}{4} \mathrm{in}$. 外 径のP-110ケーシングについてAPI(アメ リカ石油学会) の公式と(1)式より求めた ケーシングおよびカップリングの降伏圧力 と継手部の漏れ圧力の関係を示したもので ある。この図より，しめつけ回転数によつ て漏れ圧力は異なるが，(1)式より算定した
A P I 規定による 4 回転しめつけの場合の 漏れ圧力 $8610 \mathrm{psi}$ はAPI 公式より算定し たカップリングの降伏圧力 $11240 \mathrm{psi}$ より はるかに低いことがわかる。かくして，ヶ ーシングの破壊圧力は重量 $54 \mathrm{lb} / \mathrm{ft}$ 以下の ケーシングでは, ケーシングの降伏限度と 一致し, それ以上の重量のケーシングでは 継手部の漏れ圧力に一致する。また，しめ つけ回転数を増せば漏れに対する抵抗も増 加するが， A P I 公式より求めたカップリ ングの降伏圧力以上にはならない。

\section{（2）摩雄した継手部での漏れ}

第 8.2 図に扔いて, $w / t$ （ $t$ 泳ヶーシン グの摩耗前の肉厚, $w$ は摩耗後の肉厚 ) の 比が 0.14 までは内部漏れ圧力は変化せず, $w / t$ がその值以下になるとケーシソグの破 壊強度が $1800 \mathrm{psi}$ と低下するので, 継手部 の漏れによるケーシングの破壊よりもケー シングそのものが破壊する。しかしながら， $W^{\prime} / W(W$ は摩耗前のカップリングの外径, $W^{\prime}$ は摩耗後の外径)の比が減少すれば, つ まり, カップリングが摩耗してその外径が 減少すると内部漏孔抵抗は急激に減少する。 また, 外部漏れ圧力 ( (2)式 ) はヶーシング 内径の関数であるのでケーシングの摩耗に 直接影響する。しかしながら，A P I 継手 部の外部漏れ抵抗は未摩耗ケーシングの破 壊強度より大さいといわれているので, 摩 耗ケーシングの破壊強度より低い圧力で継 手部の外部漏れが生ずるかどうかさらに検 討してみる必要がある。

さらに, 著者は軸方向の引張力が作用し た場合の継手部のネジ山の飛び越しによる

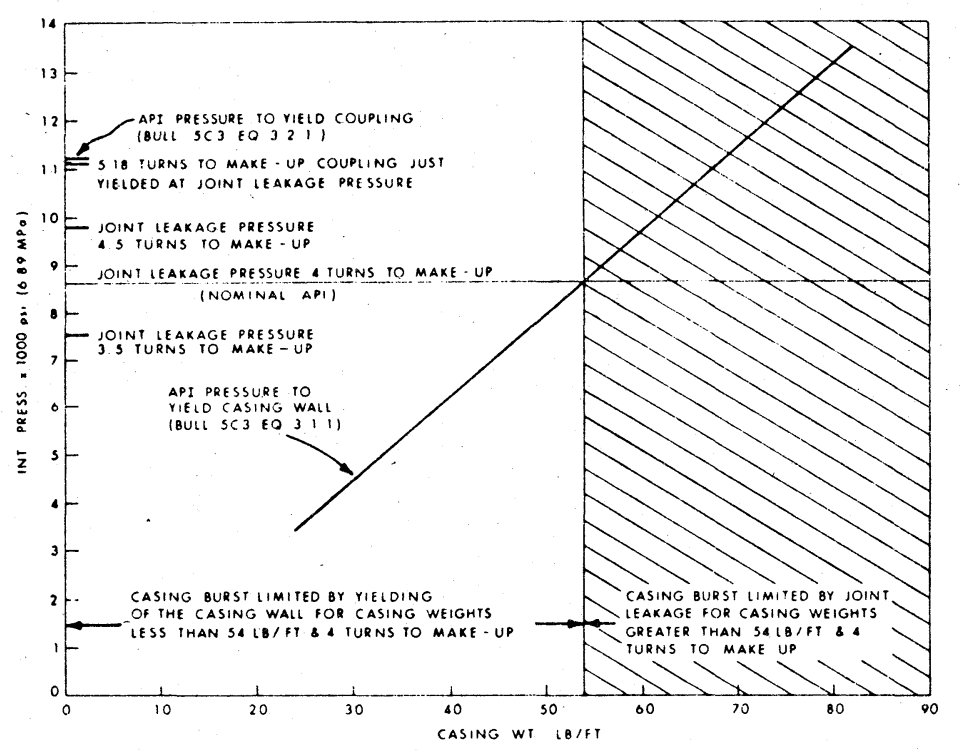

第 8・1図 API 公式による破壊圧力と継手部の漏れ 圧力の比較 (外王が作用しない場合)

第 $8 \cdot 2$ 図 ケーシングの摩耗とカップリング外径の減少が内部漏れ 抵抗におよぼす影響（ 7 in. 38- lb ケーシング )

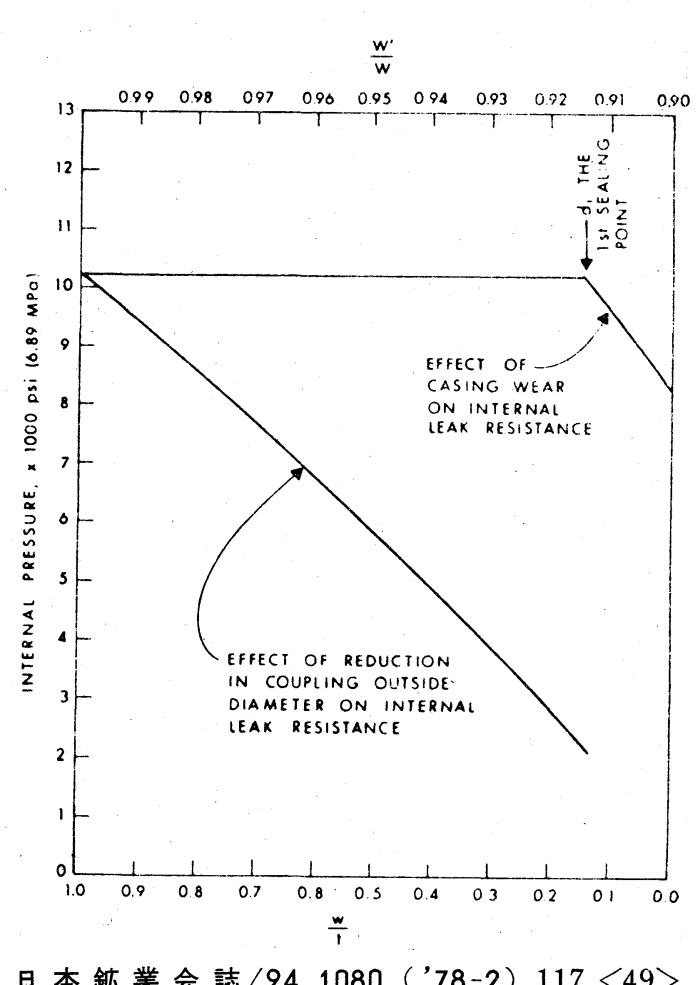

日本鉱業会誌/94 1080（'78-2） $117<49>$ 
ケーシングの破壊について研究し，ケーシ ングの外圧が上記の現象によるケーシング の引張強度を増加させることを明らかにし ている。

（秋田大 麻生和夫・菅 勝重）

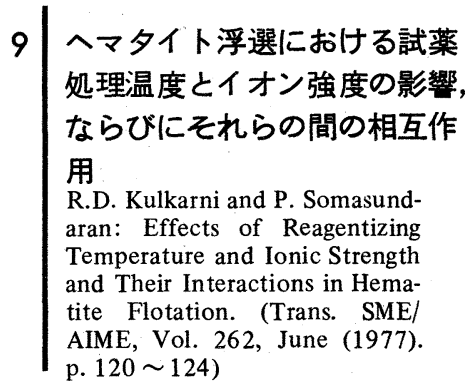

鉄鉱石の浮選においてパルプの加温が効 果的であるいくつかの例はすでに知られて いる。本論文ではへマタイトのオレイン酸 浮選における温度の影響を, イオン強度や パルプ $\mathrm{pH}$ と相関させて検討を行なつてい る。ハリモンドセルを用い, 室温で行なつ たーマタイトのオレイン酸浮選の浮鉱率は, イオン強度の増加と共に増加の傾向が認め られる(第 $9 \cdot 1$ 図) (イオン強度は $\mathrm{KNO}_{3}$ あるいはKClによつて調節している)。こ の挙動は, へマタイトのアミン浮選などに おいて, 無機電解質が捕収剂との競争吸着 によつて抑制剤として作用する挙動と対象 的である。また, 室温において, 浮鉱率に およぼすイオン強度の影響が最も顕著にな るのは中性 $\mathrm{pH}$ 付近においてであつた。

液温を上昇させるとへマタイトの浮鉱率 の向上が認められるが, これは溶液のイオ ン強度の低い場合のみであり，イオン強度 を増すと浮鉱率は逆に減少する結果になる。 これらの関係が $\mathrm{pH} 8.0$ の場合について第 $9 \cdot 2$ 図に示されている。 $\mathrm{KNO}_{3}$ を含まない 場合, 浮鉱率は温度の上昇と共に顕著に増 加するが, $\mathrm{KNO}_{3} 2 \times 10^{-1} \mathrm{~N}$ 存在下では, 温度の上昇はかえつて浮鉱率を低下させて いる。

室温において $\mathrm{KNO}_{3}$ を添加した場合浮鉱 率が上昇するのは, 電解質添加による塩析 効果によりオレイン酸ナトリウムの溶解度 が減少し，これによつて鉱物／水溶液界面 （気/液界面も同様）におけるオレイン酸 ナトリウムの吸着密度が高くなることによ るものと解釈されている。温度を高くする とこの塩析効果が失なわれるので浮鉱率が 低下するものと考えられている。オンイン 酸イオンのヘマタイト表面に対する吸着は 静電的要素を含みはするが, 化学吸着性が 強いので温度の上昇と共に吸着量が増加し ヘマタイトの浮鉱率の増加することが期待 される。インン強度の低い場合 $\left(\mathrm{ONKNO}_{3}\right)$ は予想通りの結果になつている。イオン強

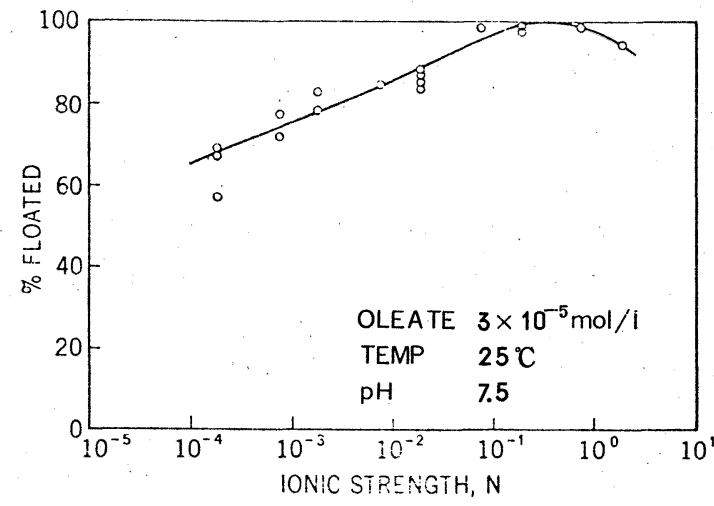

第 9.1図 ヘマタイト浮鉱率とイオン強度との関係

1 図に示すような構造をも う大小 2 種類の電解槽を製 作した。小さな電解槽の能 力は $1 \sim 1.5 \mathrm{~m}^{3} / \mathrm{h}$ であり， 大きな電解槽は直径 $350 \mathrm{~mm}$

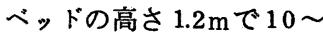
$15 \mathrm{~m}^{3} / \mathrm{h}$ の能力を有する。 電解槽はデッドスペースが できるだけ小さくなるよう に設計され，十分大きな強 度と十分小さな透水性を有 する隔膜を使用して, 陰極 室および陽極室で起こるト ラブルをなくした。流動床 電解装置の全体を第 10.2 図に示す。陽極 液および陰極液の循環系統は別々に分離さ れており, 高電流密度で発生する硫酸ミス 卜を避けるために陽極液循環系統には， Demis ter のついた酸素分離器が取り付け られている。陰極液には適宜金属含有液が 補給され, 水素分離器を通して循環され, 脱金属された電解夜は外部へ排出される。

実験はｉ）クロル炭化水素を报つている 工場排水からの $\mathrm{Cu}$ の除去, ii ）クロルー アルカリ電解工場排水からの $\mathrm{Hg}$ の除去,

iii）銅一亜鉛鉱山坑内水からの $\mathrm{Cu}$ の回収, iv）その他 $\mathrm{Co}, \mathrm{Ni}, \mathrm{Ag}, \mathrm{Zn}, \mathrm{Fe}^{3+} \rightarrow \mathrm{Fe}^{2+}$ の還元などについて行なわれ，その結果が 記述されているが，ここでは一例として i）について説明する。 $\mathrm{HCl} 5-30 \mathrm{~kg} / \mathrm{m}^{3}$, $\mathrm{Cu}^{2+}: 30-100 \mathrm{~g} / \mathrm{m}^{3}, \mathrm{Al}^{3+}: 10-200$
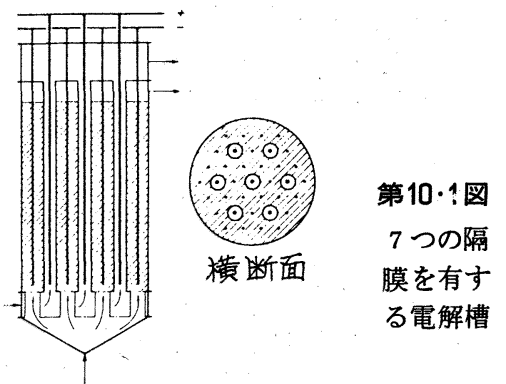
応した。

（東北大 日井進之助）

$10 \mid \begin{aligned} & \text { 希薄溶液から金属を除去する } \\ & \text { ための流動床電解 } \\ & \text { Chris M.S. Raats, Herman F. } \\ & \text { Boon, Wim Eveleens: Wirbelbett- } \\ & \text { elektrolyse zur Entfernung von } \\ & \text { Metallen aus verdünnten Lösun- } \\ & \text { gen (Erzmetall, Bd. } 30 \text { (1977), } \\ & \text { p. 365 369) }\end{aligned}$

工場排水 (廃水), 坑内水, 浸出液のよ うな希薄溶液から金属を除去するに当つて, 技術的に可能な流動床電解槽を構成して実 験し, 得られた結果について経済的な検討 が加えられている。

同心円筒型電解槽の応用型として第 10 .

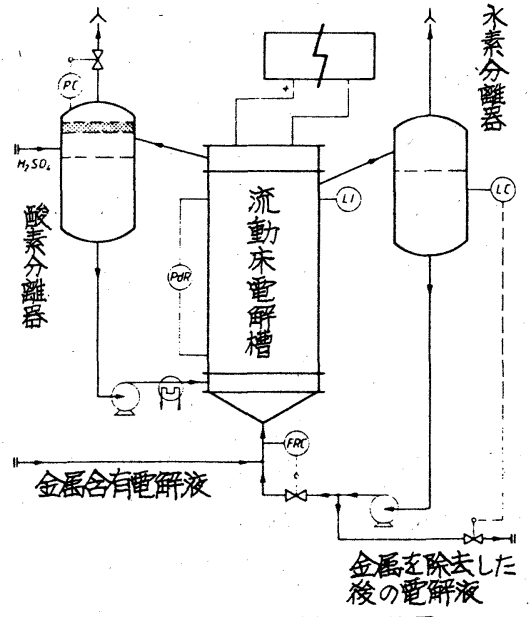

第 $10 \cdot 2$ 図 流動床電解装置 
第 10.1表 銅除去法のコストの比較

\begin{tabular}{|c|c|c|}
\hline 方 & $\begin{array}{c}\text { 投 資 費 } \\
\text { Hfl. }\end{array}$ & $\begin{array}{c}\text { 可 変 } \text {. 費 } \\
\mathrm{Hfl} / \mathrm{a} .\end{array}$ \\
\hline $\begin{array}{l}\text { 流動 床 電 解 } \\
\text { オ 交換 } \\
\text { 沈殿 / 真空洰過 }\end{array}$ & $\begin{array}{r}750,000 \\
750,000 \\
1,200,0000\end{array}$ & 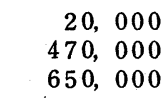 \\
\hline
\end{tabular}

$\mathrm{g} / \mathrm{m}^{3}, \mathrm{Fe}^{3+}: 5-50 \mathrm{~g} / \mathrm{m}^{3}$, クロル炭化水 素: $0-16 \mathrm{~kg} / \mathrm{m}^{3}$, 固形物 : $0.5-5 \mathrm{~kg} / \mathrm{m}^{3}$ なる組成の溶液を $1 \mathrm{~m}^{3} / \mathrm{h}$ の能力を有する 電解槽で 1 回処理し, 約 $70 \%$ の電流効率 で $\mathrm{Cu} 1 \mathrm{~g} / \mathrm{m}^{3}$ まで低下した。この際多 量の固形物やクロル炭化水素の妨害は全く 認められなかつた。

この処理費を他の方法による処理費と比 較したのが第 $10 \cdot 1$ 表である（Hf $1 \doteqdot 104$ 円，昭和 52 年 12 月 12 日現在）。投資費 のうち熱交換器および耐食性構造材料が約 $50 \%$ を占める。可変費はエネルギーおよ び薬品の使用並びに労務費用からなる。イ オン交換法や沈殿法ではアルカリ液を使用 するので流動床電解に較べて可変費が高い。 回収された Cu $1 \mathrm{~kg}$ 当りの費用を処理液

\section{第 $10 \cdot 3$ 図 流動床電解に おける金属の 生産費}

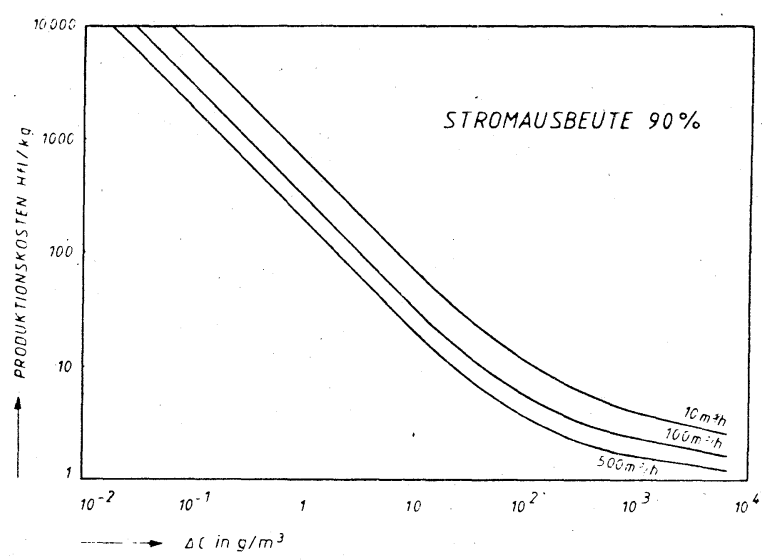

の濃度と流量の関数として示すと第 $10 \cdot 3$

60 で2価の銅以外の金属イオンに対しても 困のようになる。生産費は金利, 減価償却 費, 維持費, 利潤, 運転費, エネルギー費, 薬品費および金属粒子製造費を含む。約 $150 \mathrm{~g} / \mathrm{m}^{3}$ までの低い濃度では 1 台の電解 槽で十分であるが, それ以上の濃度では濃 度により 2 台またはそれ以上の電解槽を直 列に設置しなければならない。 $100 \mathrm{~g} / \mathrm{m}^{3}$ 以下の濃度では生産費は電流効率にほとん ど無関係になるので, 同図は原子量が約
まずまずの精度で適用することができる。 例えば, $100 \mathrm{~g} / \mathrm{m}^{3}$ の金属濃度を有する溶液 を $10 \mathrm{~m}^{3} / \mathrm{h}$ の流量で処理すると，その価格 が約 $10 \mathrm{Hf} 1 / \mathrm{kg}$ 以上の金属の回収ならば 採算が取れる。もつと濃度が高く流量が大 きい場合にはより安価な金属の回収でも採 算に合う。ただし，この見積りは，溶液費 が零あるいは溶液が負価値を有しないことを 前提としている。（名古屋大 山内睦文）

\begin{tabular}{|c|c|c|c|c|c|c|c|c|c|c|c|}
\hline \multirow{2}{*}{\multicolumn{2}{|c|}{ 雑音楽記 }} & \multirow{2}{*}{\multicolumn{2}{|c|}{ （p. 42の付表 ) }} & $\mathrm{Rb}$ & 123. 06 & 6. 9441 & \multicolumn{4}{|c|}{ 以下ランンタ } & \multirow{2}{*}{$\# \mathrm{~A}$} \\
\hline & & & & $\mathrm{Sr}$ & 211.56 & 7. 7252 & A & $\mathrm{La}$ & 229.30 & 7. 8425 & \\
\hline \multirow{4}{*}{ 第 2 表 } & \multirow{4}{*}{\multicolumn{3}{|c|}{$\begin{array}{l}\text { 板(厚さ } 0.5 \mathrm{~cm}, \text { 長さ } 43.9 \mathrm{~cm} \text { ) } \\
\text { に作った元素の横振動数 }\left(N_{1}\right) \\
\text { と該当音名 }\end{array}$}} & $\mathrm{Y}$ & 351.81 & 8. 4594 & & $\mathrm{Ce}$ & 194.75 & 7. 6066 & \\
\hline & & & & $\mathrm{Zr}$ & 600.51 & 9. 2312 & $\# d^{\prime}$ & $\mathrm{Pr}$ & 202.60 & 7. 6634 & \#G \\
\hline & & & & $\mathrm{Nb}$ & 793. 60 & 9. 6332 & $\mathrm{~g}^{\prime}$ & $\mathrm{Nd}$ & 215. 08 & 7. 7495 & $\mathrm{~A}$ \\
\hline & & & & Mo & 523. 55 & 9. 0332 & & $\mathrm{Sm}$ & 196. 69 & 7. 6209 & \\
\hline 元素名 & $N_{1}$ & $\log N_{1} / \log 2$ & 該当音名 & $\mathrm{Te}$ & 524. 01 & 9. 0342 & & $\mathrm{Eu}$ & 157. 06 & 7. 2963 & \\
\hline $\mathrm{Li}$ & 429. 87 & 8. 7488 & $\mathrm{a}$ & $\mathrm{Ru}$ & 503. 60 & 8. 9770 & & Gd & 246. 58 & 7. 9468 & \\
\hline $\mathrm{Be}$ & 1172. 75 & 10. 1970 & $d^{\prime \prime}$ & $\mathrm{Rh}$ & 506.46 & 8. 9853 & $c^{\prime}$ & $\mathrm{Tb}$ & 243. 53 & 7. 9285 & $\mathrm{H}$ \\
\hline $\mathrm{B}$ & 1237. 42 & 10. 3196 & $e^{\prime \prime}$ & $\mathrm{Pd}$ & 296. 47 & 8. 2126 & & Dy & 250.64 & 7. 9697 & \\
\hline $\mathrm{Na}$ & 280.58 & 8. 1332 & & $\mathrm{Ag}$ & 256. 00 & 8. 0006 & $\mathrm{c}$ & Ho & 255.08 & 7. 9956 & c \\
\hline $\mathrm{Mg}$ & 466. 27 & 8. 8661 & & $\mathrm{Cd}$ & 248. 06 & 7. 9558 & & $\operatorname{Er}$ & 262.93 & 8. 0392 & \\
\hline Al & 473. 76 & 8. 8890 & $\mathrm{~h}$ & In & 110.68 & 6. 7906 & & $\mathrm{Tm}$ & 262. 84 & 8. 0385 & \\
\hline $\mathrm{S} \mathrm{i}$ & 614. 18 & 9. 2634 & $\# d^{\prime}$ & $\mathrm{Sn}$ & 251. 11 & 7. 9730 & & $\mathrm{Yb}$ & 141. 63 & 7. 1358 & \\
\hline $\mathrm{K}$ & 187. 45 & 7. 5514 & & $\mathrm{Sb}$ & 266. 07 & 8. 0568 & & $\mathrm{Lu}$ & 270.51 & 8. 0808 & $\# \mathrm{c}$ \\
\hline $\mathrm{Ca}$ & 328. 62 & 8. 3611 & & $\mathrm{Cs}$ & 88. 78 & 6. 4727 & & 以下 & チ=ド元 & & \\
\hline $\mathrm{S} \mathrm{c}$ & 475.05 & 8. 8926 & in & $\mathrm{Ba}$ & 172.02 & 7. 4269 & $\mathrm{~F}$ & $\mathrm{Ac}$ & 170.55 & 7. 4139 & $\mathrm{~F}$ \\
\hline $\mathrm{T} \mathrm{i}$ & 447. 70 & 8. 8073 & & $\mathrm{Hf}$ & 297. 02 & 8. 2152 & & $\mathrm{Th}$ & 233. 18 & 7. 8664 & \#A \\
\hline $\mathrm{V}$ & 428. 76 & 8. 7448 & $\mathrm{a}$ & $\mathrm{T} \mathrm{a}$ & 305.43 & 8. 2554 & $\# d$ & $\mathrm{~Pa}$ & 235.49 & 7. 8803 & $\mathrm{H}$ \\
\hline $\mathrm{Cr}$ & 536. 95 & 9. 0687 & $\# c^{\prime}$ & $\mathrm{W}$ & 421.56 & 8. 7205 & $\mathrm{a}$ & $\mathrm{U}$ & 290.09 & 8. 1810 & $d$ \\
\hline $\mathrm{Mn}$ & 476. 99 & 8. 8986 & $\mathrm{~h}$ & $\mathrm{Re}$ & 429. 78 & 8. 7485 & a & $\cdot \mathrm{Np}$ & 209. 25 & 7. 7099 & \\
\hline $\mathrm{Fe}$ & 477. 36 & 8. 9000 & $\mathrm{~h}$ & $\mathrm{Os}$ & 451. 31 & 8. 8189 & $\#$ a & $\mathrm{Pu}$ & 204. 08 & 7. 6739 & $\# \mathrm{G}$ \\
\hline $\mathrm{Co}$ & 444. 38 & 8. 7966 & & I r & 447. 33 & 8. 8059 & & $c: t$ & 八音, $N$ & $2^{8}=2$ & 1オク \\
\hline $\mathrm{Ni}$ & 430.15 & 8. 7495 & a & $\mathrm{Pt}$ & 260.44 & 8. 0255 & c & & の音, & オクタ & の音, \\
\hline $\mathrm{Cu}$ & 343. 12 & 8. 4232 & $f$ & $\mathrm{Au}$ & 185.60 & 7. 5368 & $\# \mathrm{~F}$ & 大文字 & 1 オクタ & క゙下の音, & 字の下 \\
\hline $\mathrm{Zn}_{\mathrm{n}}$ & 331. 94 & 8. 3754 & & $\mathrm{~T} 1$ & 75.66 & 6. 2418 & $\# D_{1}$ & つき 1 & 例 $C_{1}$ ) & オクター & 音, \# \\
\hline $\mathrm{Ga}$ & 356. 15 & 8. 4767 & & $\mathrm{~Pb}$ & 108. 37 & 6. 7611 & $A_{1}$ & は半音 & W音。 & & \\
\hline $\mathrm{Ge}$ & 398. 28 & 8. 6385 & & $\mathrm{~B} \mathrm{i}$ & 172. 39 & 7. 4302 & $\mathrm{~F}$ & & & (p. 5 & D \\
\hline
\end{tabular}

